\title{
Kjønnsforskjeller i suicidal atferd
}

\author{
Ingeborg Rossow \\ Statens institutt for alkohol- og narkotikaforskning, Dannevigsveien 10, 0463 Oslo \\ e-post: ingeborg.m.rossow@sifa.no
}

Selvpåførte skader, med eller uten dødelig utgang, representerer et betydelig helseproblem på flere måter. Blant unge voksne er selvmord en vanlig dødsårsak. En fjerdedel av dem som dør i alderen 15 til 24 år, har tatt sitt eget liv, og selvmord er nest etter ulykker den vanligste dødsårsaken for gutter i denne aldersgruppen (Hytten et al., 1995). Selvmordsforsøk er vesentlig mer utbredt, særlig blant ungdom og unge voksne, og signaliserer ofte en vanskelig livssituasjon (Hjelmeland, 1999).

Et slående trekk ved suicidal atferd er at det er betydelige kjønnsforskjeller i omfanget, og at disse forskjellene er omvendte for fullbyrdete selvmord og for selvmordsfors $ø$. Dette til tross for at selvmord og selvmordsforsøk har mange likhetstrekk og felles risikofaktorer, og at mange selvmord etterfølger ett eller flere selvmordsforsøk. Jeg vil i det følgende beskrive noen viktige trekk ved kjønnsforskjellene i suicidal atferd og diskutere noen mulige forklaringer.

\section{SELVMORD}

\section{Selvmordsrater for kvinner og menn}

Forekomsten av selvmord er gjennomgående vesentlig høyere blant menn enn blant kvinner, og dette er ganske konsistent $i$ en rekke vestlige industrialiserte land gjennom mer enn de siste hundre år. I Norge i etterkrigstiden har selvmordsraten for menn ligget på omkring 15 per 100.000 per år (varierende mellom 10 og 25), mens selvmordsraten for kvinner har ligget omkring 5 per 100.000 (varierende mellom 3 og 9). I 1995 var det $i$ alt 411 menn og 137 kvinner som tok sitt eget liv, det vil si tre ganger så høy forekomst blant menn som blant kvinner (Statistisk sentralbyrå, 1998). Figur 1 viser kjønnsspesifikke selvmordsrater for perioden 1971-1995, og som vi ser, er trendene for kvinner og menn ganske parallelle, og rate ratioen varierer mellom 2,5 og 3 . Selvmordsratene er lavest i de yngste aldersgruppene, både for kvinner og menn, men de største kjønnsforskjellene i selvmordsrater finner vi blant ungdom og unge voksne og blant de eldste. For menn er forekomsten omtrent like høy blant eldre som blant middelaldrende, mens det for kvinner igjen er en lavere rate i de eldste aldersgruppene (Figur 2).

En vesentlig lavere forekomst av selvmord blant kvinner sammenliknet med menn finner vi også gjennomgående $\mathrm{i}$ andre land hvor det er ført selvmordsstatistikk, både i land med betydelig lavere selvmordsforekomst enn i Norge (slik som i de fleste katolske

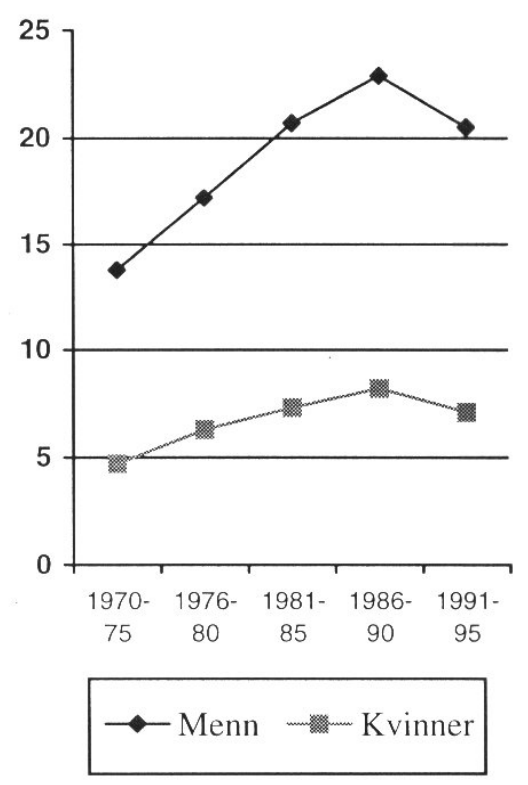

Figur 1. Selvmordsrater for perioden 1971-1995 for menn og kvinner. Kilde: Statistisk Sentralbyrå, 1998.

land) og i land med betydelig høyere selvmordsforekomst (som blant annet Ungarn og Finland).

\section{Metoder ved selvmord}

En annen gjennomgående kjønnsforskjell ved selvmord er valg av metode. Menn bruker i betydelig større grad enn kvinner såkalte definitive metoder, dvs. selvmord ved hengning og skyting, mens kvinner i større grad bruker såkalt myke metoder, spesielt egenforgiftninger med legemidler, gass eller andre gifter (Figur 3). I Norge utgjør forgiftninger ca. $28 \%$ av alle selvmordsdødsfall, blant menn skjer ca. $17 \%$ av selvmordene ved forgiftning, mens blant kvinner er $43 \%$ av selvmordene ved forgiftninger. Over halvparten av alle selvmordene i Norge (54\%) skyldes hengning eller skyting, og disse metodene er vesentlig mer utbredt blant menn (64\%) enn blant kvinner (26\%) ${ }^{1}$.

\section{Endringer i omfang og metoder}

Selvmordsratene økte betydelig i Norge i perioden mellom 1960 og 1988 (mer enn fordobling), men de har i de senere årene sunket noe igjen. Økningen i 


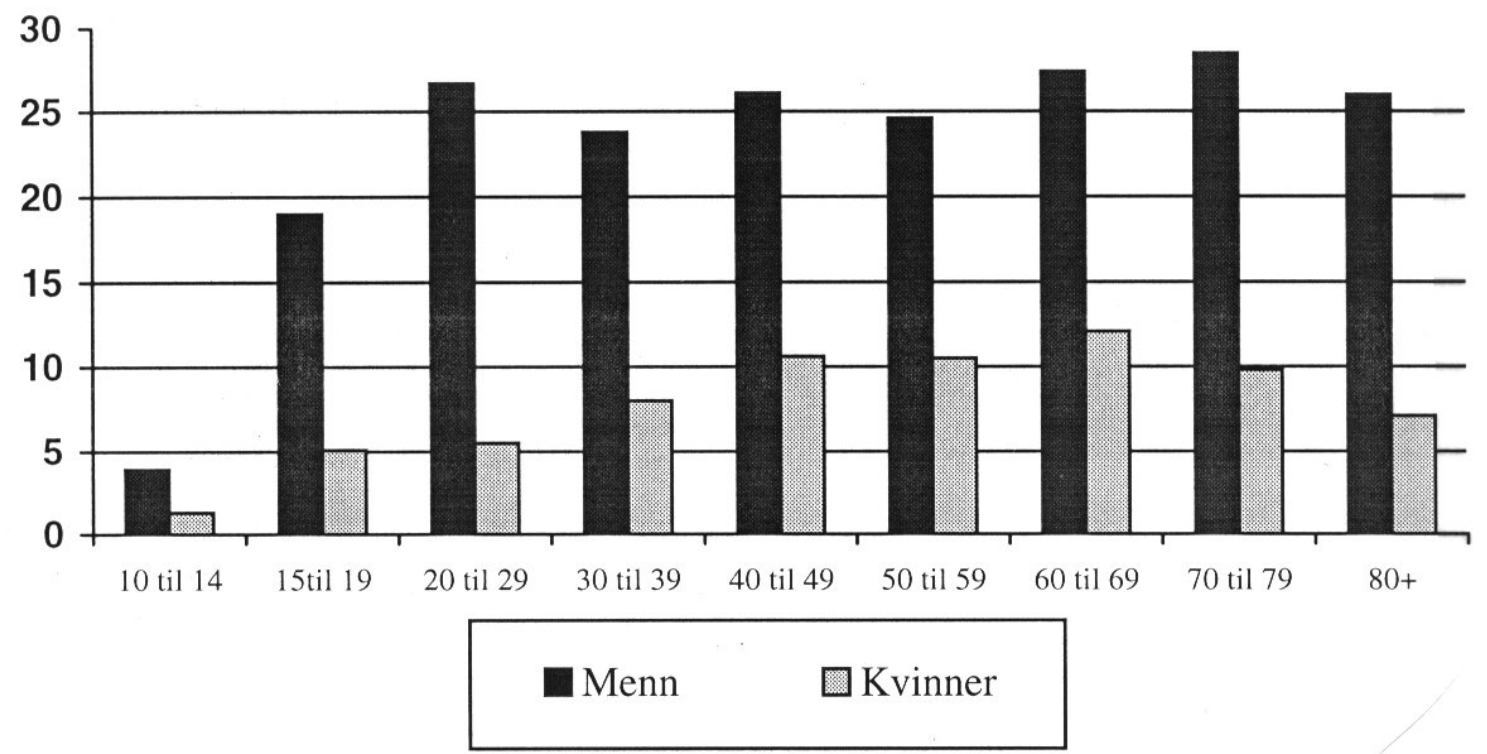

Figur 2. Selvmordsrater etter aldersgrupper og kjønn for perioden 1990-1995. Kilde: Statistisk Sentralbyrå, 1998.
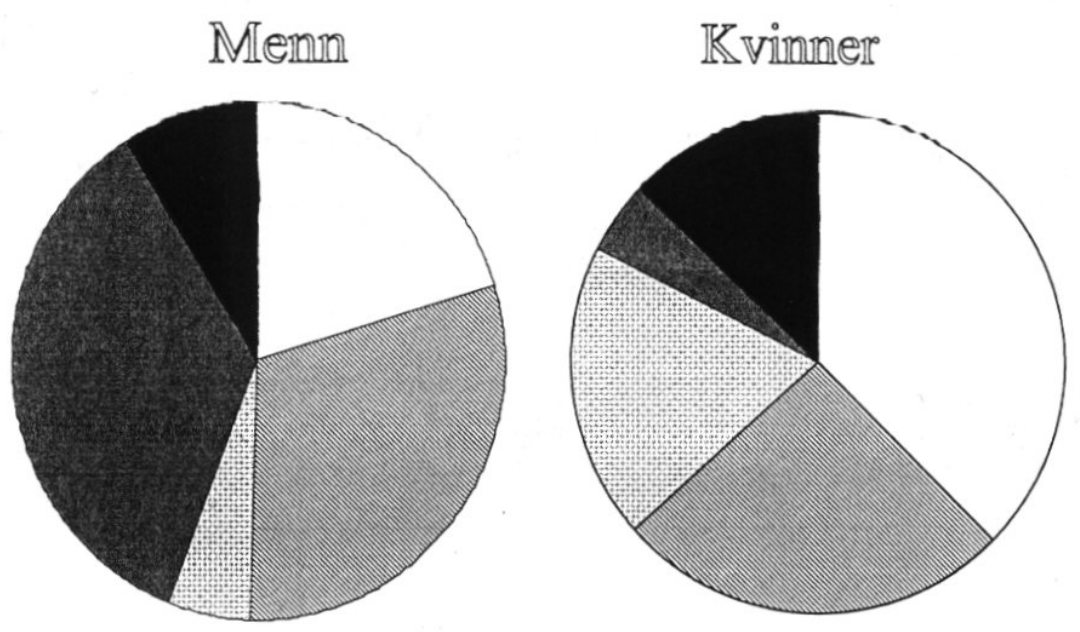

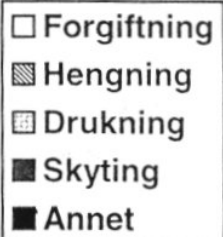

Figur 3. Fordeling av metoder for selvmord blant menn og kvinner. Tall fra perioden 1991-1995. Kilde: Statistisk sentralbyrå 1998 .

selvmordsrater skjedde for begge kjønn (se Figur 1), men i større grad blant menn og særlig blant unge menn. I denne gruppen har økningen i selvmordsrater særlig vært knyttet til økt bruk av definitive metoder. Også blant unge jenter har det skjedd en økning i bruk av hengning og skyting (Hytten et al., 1995).

\section{Risikofaktorer}

Vurderinger av årsaker og risikofaktorer for selvmord vil variere med teoretisk ståsted og disiplinforankring. Innenfor den medisinske eller psykiatrisk orienterte delen av litteraturen vil psykiske lidelser som schizofreni og depresjon og rusmiddelmisbruk gjennomgående være sentrale risikofaktorer for selvmord.
Innenfor den samfunnsvitenskapelige litteraturen har sosiale og økonomiske forhold som svekket sosial tilhørighet og arbeidsløshet vært hyppig nevnte risikofaktorer. Dette er risikofaktorer som trolig supplerer hverandre med tanke på å forklare både individuell variasjon i risiko for selvmord og variasjoner på aggregert nivå i selvmordsrater. Samtidig vil slike risikofaktorer ofte også være forbundet med hverandre. Eksempelvis finner man ofte at rusmiddelmisbruk henger sammen med både depresjon, arbeidsløshet og svekket sosial tilhørighet (Maris et al., 1992, Retterstøl, 1995; Hammerlin \& Schjelderup, 1994).

Blant unge mennesker er ustabile oppvekstforhold (pga. skilsmisse, rusmiddelmisbruk eller psykiske lidelser blant foreldrene) og selvmord i familien eller 
nærmiljøet også viktige risikofaktorer for selvmordsatferd (Bjerke, 1991).

En risikofaktor som synes å være særlig sterk med hensyn på selvmord er tidligere selvpåførte skader eller selvmordsforsøk. En betydelig andel av dem som har tatt sitt eget liv (30-50\%) har hatt ett eller flere tidligere selvmordsforsøk (Retterstøl, 1995), og blant dem som har vært innlagt i sykehus for selvmordsforsøk vil omtrent 10\% seinere ta sitt eget liv (Rygnestad, 1991). Det er altså en betydelig overlapping mellom selvpåførte skader med og uten dødelig utgang.

\section{SELVPÅFØRTE SKADER - SELVMORDSFORSØK}

Forekomsten av selvmordsforsøk eller parasuicid er vesentlig større enn forekomsten av selvmord. Det finnes ingen nasjonal registrering av forekomsten av sykehusinnleggelser for selvmordsfors $ø \mathrm{k}$. Ved regionsykehuset $\mathrm{i}$ Trondheim er det gjort en systematisk kartlegging av selvmordsforsøk i en årrekke, og dette har gitt et godt grunnlag for å angi omfanget av selvmordsforsøk og utvikling over tid. Ratene for selvmordsforsøk her har gjennom det siste ti-året ligget på omkring 200 per 100.000 for kvinner og omkring 150 per 100.000 for menn (Hjelmeland \& Bjerke, 1994), men trendene har vært klart synkende gjennom 90tallet, og kjønnsforskjellene er blitt vesentlig mindre (Hjelmeland, 1999). Studier både fra norske sykehus og sykehus $i$ andre vestlige land, viser nesten entydig ${ }^{2}$ at forekomsten av selvmordsforsøk er høyere blant kvinner enn blant menn. Det antas at det årlig er omkring 8-9000 personer i Norge som innlegges i sykehus for selvmordsfors $ø \mathrm{k}, \mathrm{og}$ at det $\mathrm{i}$ aldersgruppen under 30 år er 1800-1900 kvinner og ca. 1100 menn med selvmordsforsøk i sykehus (Bjerke, 1991). Til forskjell fra selvmord, er selvmordsforsøk mer hyppig forekommende blant unge og middelaldrende enn blant eldre, og dette gjelder for begge kjønn (Kerkof et al., 1994). Det er også blant de unge at kjønnsforskjellene i selvmordsrater er størst, og blant ungdom er forekomsten av selvmordsforsøk funnet å ligge 3 til 9 ganger høyere for jenter enn for gutter (Bjerke, 1990), mens det er små kjønnsforskjeller i ratene for middelaldrende og eldre (Hjelmeland, 1999). Andre studier har også vist en betydelig overvekt av jenter blant de unge selvmordsforsøkerne. Haukø (1997) fant at det var 4-5 ganger flere jenter enn gutter under 18 år som var innlagt på Bærum sykehus med selvmordsforsøk, og i en britisk studie (Hawton et al., 1982) var 90\% av tenåringene som ble lagt inn på sykehus med egenforgiftninger, jenter.

Også spørreundersøkelser i utvalg av befolkningen viser at kvinner rapporterer om selvmordsforsøk omtrent dobbelt så ofte som det menn gjør (Bjerke, 1990; Rossow \& Wichstrøm, 1994). I et nasjonalt utvalg på nærmere 12.000 skoleungdom mellom 12 og 20 år (Ung i Norge-studien) var det $10,5 \%$ av jentene og $6 \%$ av guttene som rapporterte at de noen gang hadde forsøkt å ta sitt eget liv (Rossow \& Wichstrøm, 1994).
Beregninger fra denne studien gir et anslag på omkring 1500 tilfeller av selvpåførte skader per 100.000 per år for jenter og omkring 800 selvpåførte skader per 100.000 per år for gutter. I en studie av 15-24-åringer i Danmark fant Jessen og medarbeidere (1996) omtrent tilsvarende rater; 1340 for jenter og 580 for gutter. Som vi ser, er altså forekomsten av slike selvrapporterte selvmordsforsøk eller selvpåførte skader vesentlig høyere enn forekomsten av selvmordsforsøk i sykehus (se Figur 4).

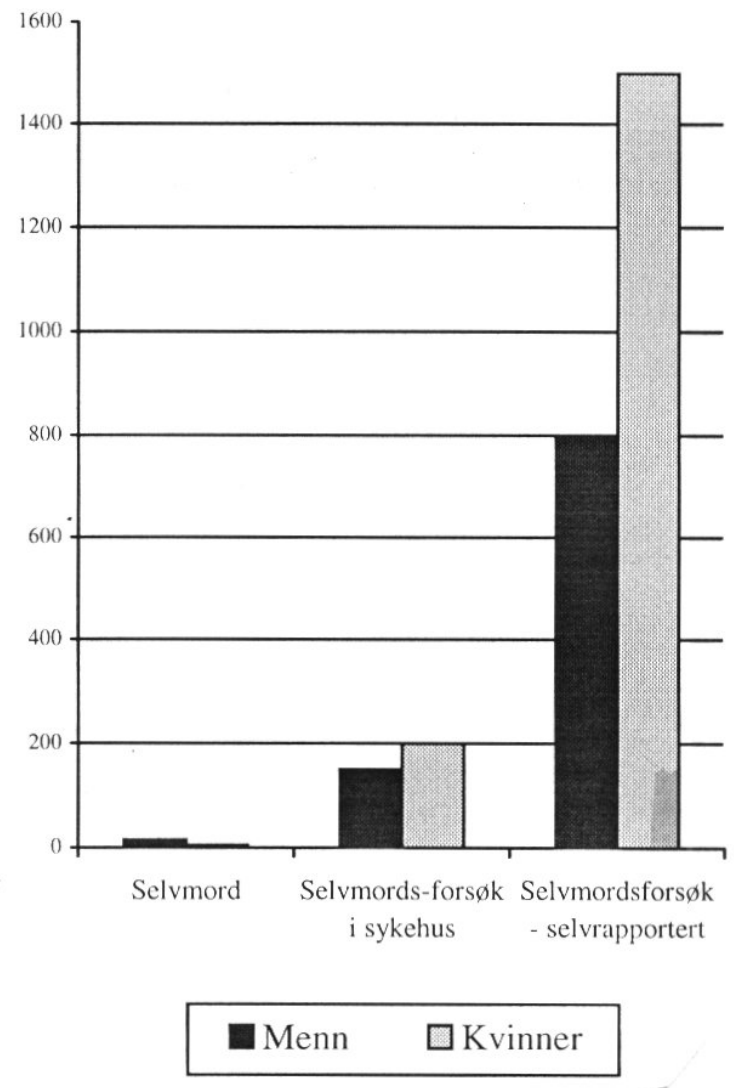

Figur 4. Forekomst av selvmord, selvmordsforsøk (sykehusinnleggelser) og selvrapporterte selvmordsforsøk blant ungdom (14-20 år) for kvinner og menn. Angitt i antall per $100.000 \mathrm{i}$ befolkningen per år. Rater for selvmordsforsøk med sykehusinnleggelse er basert på undersøkelser i Sør-Trøndelag (Hjelmeland og Bjerke, 1994), og rater for selvmordsforsøk blant ungdom er basert på data fra Ung-i-Norge-studien (Rossow og Wichstrøm, upubliserte estimater).

\section{Metoder ved selvmordsforsok}

Mens selvmord i stor grad skjer ved bruk av definitive metoder (hengning og skyting), er selvmordsforsøkene i det alt overveiende foretatt ved egenforgiftning med medikamenter eller kutt-/stikkskader, og det er mindre kjønnsforskjeller i valg av metode ved selvmordsforsøk. Av selvmordsforsøkene som sees ved sykehusinnleggelser, skjer nærmere $90 \%$ av forsøkene blant kvinner ved forgiftning, mens blant menn utgjør egenforgiftningene omlag 75\% (Hjelmeland \& Bjerke, 1994). 
I spørreundersøkelsen "Ung i Norge" (Rossow \& Wichstrøm, 1997) rapporterte halvparten av dem med selvmordsforsøk at de hadde kuttet eller stukket seg ved (det siste) selvmordsforsøket, mens forgiftninger med tabletter/medikamenter var benyttet $\mathrm{i}$ en tredjedel av tilfellene. Det var ingen vesentlige kjønnsforskjeller i metode blant disse unge selvmordsforsøkerne.

\section{Risikofaktorer for selvmordsforsok}

Ettersom selvmordsforsøk ofte går forut for et selvmord, finner vi mange av de samme risikofaktorene for selvmordsatferd, enten utgangen er dødelig eller ikke. Depresjon og håpløshetsfølelse, rusmiddelmisbruk, svakt sosialt nettverk og arbeidsløshet er risikofaktorer som går igjen i undersøkelser av personer med selvmordsforsøk (Kerkhof et al., 1994; Hjelmeland, 1999). Blant unge mennesker ser man også en overhyppighet av selvmordsforsøk blant dem som kommer fra hjem med oppløste ekteskap/parforhold, med rusmiddelproblemer eller psykiske lidelser og blant dem som har opplevd selvmordsatferd i familie eller nærmiljø. Blant dem som har vært utsatt for seksuelle eller voldelige overgrep synes også risikoen for selvmordsforsøk å være høyere (kfr. Bjerke, 1991).

\section{DE OMVENDTE KJØNNSFORSKJELLENE}

Til tross for at selvmordsforsøk er en sterk risikofaktor for seinere selvmord og at forekomsten av selvmord er vesentlig høyere blant menn enn blant kvinner, ser vi altså at omfanget av selvmordsforsøk er betydelig større blant kvinner enn blant menn. Fra et kjønnsforskjells-perspektiv er det tankevekkende at kjønnsforskjellene i selvmord og selvmordsforsøk er akkurat omvendte og at dette i stor grad er gjennomgående over tid og på tvers av kulturer. Hvordan kan dette forklares?

Blant tilnærmingene til å forklare kjønnsforskjellene i selvmordsrater, er metodevalg og sannsynlighet for å dø ved ulike metoder en forklaring som trekkes fram. Som vi har sett, er egenforgiftning med medikamenter hyppig brukt av kvinner, både ved selvmordsforsøk og ved selvmord. Både vanskene med tilstrekkelig dosering og muligheten for å bli funnet og hjulpet før man dør, gjør at metoden er mer usikker, og sannsynligheten for å dø mindre. Men er forskjellene $\mathrm{i}$ metodevalg tilstrekkelig til å forklare de paradoksale kjønnsforskjellene mellom selvmordsforsøk og fullbyrdete selvmord? Ser vi på forekomsten av forgiftningstilfeller med fatal og ikke-fatal utgang, finner vi imidlertid at dette $\mathrm{i}$ beste fall bare kan være en delforklaring. I de følgende beregningene har jeg tatt utgangspunkt $\mathrm{i}$ data fra Regionsykehuset $\mathrm{i}$ Trondheim (Hjelmeland, 1999) for å anslå omfanget av selvmordsforsøk ved forgiftninger samt SSB's dødsårsaksstatistikk for omfanget av selvmord ved egenforgiftning. Av dette kan vi anta at det i Norge har vært omkring 8000 sykehusinnleggelser etter egenforgiftninger blant menn, og om lag 11000 for kvinner $\mathrm{i}$ perioden 1991-95. I samme periode var det 89 menn og 58 kvinner som begikk selvmord ved forgiftning. Hvis vi antar at risikoen for dødsfall var knyttet til omfanget av selvpåførte forgiftninger, finner vi dermed at sannsynligheten for egenforgiftning med dødelig utgang var over dobbelt så stor for menn som for kvinner. Med andre ord, av alle tilfeller av selvpåført skade ved forgiftning, er det bare en liten andel som dør. Når denne andelen er vesentlig mindre for kvinner enn for menn, styrker dette antakelsen om at den lavere forekomsten av selvmord blant kvinner ikke bare skyldes valg av en metode som sjelden gir dødelig utfall. Hjelmelands studie (1996) viste også at blant pasienter innlagt for selvmordsforsøk, var risikoen for seinere selvmord fire ganger høyere for menn enn for kvinner.

Jeg tror at ett viktig utgangspunkt for å forklare disse omvendte kjønnsforskjellene er at fullbyrdete selvmord og selvmordsforsøk (eller parasuicid) i flere henseender er ulike handlinger. Det er riktignok mange likhetstrekk mellom selvmord og selvmordsforsøk, både med hensyn til personkarakteristika og utløsende faktorer. Men mange, eller antakelig de fleste, selvpåførte skader er ikke "mislykkete forsøk" på å ta sitt eget liv. Ofte er en slik selvmordsatferd også preget av ambivalens til om man ønsker å dø eller ikke (Retterstøl, 1995). En rekke studier har vist at for mange av dem som har påført seg selv skader, var hensikten ikke å dø, men noe annet; å komme bort fra en vanskelig situasjon, å manipulere omgivelsene (få noen til å føle skyld eller teste ut andres kjærlighet), eller synliggjøre at man har det vondt ("et rop om hjelp") (Hjelmeland, 1999) ${ }^{3}$. I studien fra Regionsykehuset i Trondheim (Hjelmeland, 1996) var det om lag halvparten av pasientene som sa at de ønsket å dø. I studien av selvrapporterte selvmordsforsøk blant ungdom (Rossow \& Wichstrøm, 1997) var det om lag en ti-del som oppga at de ønsket å dø.

Raymond Jack (1992) mener at når kvinner oftere begår selvmordsforsøk, men i mindre grad enn menn begår selvmord, så handler dette om ulike kjønnsroller. Kvinnerollen innebærer en "lært hjelpeløshet", hevder Jack, og selvpåførte skader er et endepunkt i en ond spiral av reduserte handlingsmuligheter. I dette ligger at kvinner ofte har begrenset kontroll over egne liv, og i mindre grad er i stand til å mestre sine problemer selv og i stedet tyr til helsetjenesten og medikamenter. Men, "... når pillene ikke heller løser problemene, glir hjelpeløsheten over i håpløshet og egen-forgiftning”. Dette kan kanskje være en fruktbar måte å (delvis) forklare det høyere omfanget av selvpåførte skader blant kvinner enn blant menn. For egen del synes jeg nok at forklaringen halter når vi tar i betraktning at for begge kjønn er omfanget av selvmordsforsøk lavere blant middelaldrende og eldre og at kjønnsforskjellene også viskes ut i disse aldersgruppene hvor omfanget av medikamentbruk er særlig høyt, og hvor man må anta at den tradisjonelle kjønnsrollen står sterkere. Når det gjelder kjønnsforskjeller i fullbyrdete selvmord har 
f.eks. Hytten og medarbeidere (1995) også trukket fram kjønnsroller, og blant annet pekt på at økningen $\mathrm{i}$ selvmord blant unge menn, og særlig i utkantområder, kan forklares med strukturelle endringer (f.eks. i arbeidsmarkedet) som det har vært vanskeligere å tilpasse seg innenfor den tradisjonelle mannsrollen. Det er likevel påfallende $\mathrm{i}$ hvor liten grad de omvendte kjønnsforskjellene i suicidal atferd har vært gjenstand for teoretisk diskusjon og forsøk på forklaringer.

\section{BEHANDLING OG FOREBYGGING}

Behandlingen av pasienter som har vært innlagt $i$ sykehus for selvmordsforsøk varierer nok mye, men mange steder blir pasienter med selvmordsforsøk kun gitt en somatisk behandling av forgiftningen, og i Oslo er det mindre enn $10 \%$ av pasientene som overflyttes til en psykiatrisk avdeling etter et selvmordsforsøk (Helsedirektoratet, 1993). Mange selvpåførte skader blir imidlertid ikke behandlet innenfor helsevesenet $\mathrm{i}$ det hele tatt. En spørreundersøkelse blant norske ungdommer viste at $\mathrm{i}$ underkant av $20 \%$ av de som hadde hatt selvmordsforsøk hadde fått behandling i helsetjenesten etterpå, og det var en høyere andel av jentene enn av guttene som hadde fătt behandling hos psykolog eller psykiater. Omlag en tredjedel av ungdommene med selvmordsforsøk hadde fått hjelp hos venner, mens halvparten oppga at de ikke hadde fått hjelp eller behandling hos noen etter selvmordsforsøket. Andelen som ikke hadde fått hjelp eller behandling hos noen var vesentlig høyere blant gutter (63\%) enn blant jenter (44\%) (Rossow \& Wichstrøm, 1997).

Også de som har mistet en nær pårørende i selvmord vil gjerne ha behov for hjelp eller behandling til å bearbeide tapet, sorgen og ofte også skyldfølelse. Helsepersonell og prester eller menighetsforstandere vil ofte ha en viktig rolle i dette sorgarbeidet (Helsedirektoratet, 1993).
Med bakgrunn i den betydelige økningen i forekomsten av selvmord gjennom 1970- og 80-årene fikk Statens Helsetilsyn (daværende Helsedirektoratet) utarbeidet et program for forebygging av selvmord $\mathrm{i}$ Norge (1993). Utredningen som lå til grunn for programmet, peker på en rekke mulige virkemidler for å begrense omfanget av selvmord og selvpåførte skader. Disse omfatter blant annet:

- bedre behandling og oppfølging etter selvmordsforsøk (kfr. "Bærums-modellen")

- bedre diagnostikk og behandling av depresjoner $\mathrm{i}$ befolkningen

- opprustning av det psykiatriske behandlingstilbudet

- forebygging av rusmiddelproblemer, styrking av sammenhengende tiltakskjeder for rusmiddelmisbrukere og bedring av diagnostikk av selvmordsfare i denne gruppen

- styrking av skolens rolle i primær- og sekundærforebyggende arbeid (skolehelsetjeneste, PP-tjeneste, lærernes kunnskaper og elevenes sosiale ferdigheter)

- mer forskning, blant annet for bedre å kartlegge risikofaktorer og mulige effekter av tiltak.

Ved Bærum sykehus har man utviklet en modell for oppfølging av pasienter med selvmordsforsøk, og et tverrfaglig team tilrettelegger og koordinerer tilbud av ulike hjelpetilbud både for pasienten og familien (Burmo et al., 1990). Resultatene fra dette arbeidet har vært svært gode, og det er derfor anbefalt at andre kommuner også tilpasser "Bærums-modellen" ved oppfølging etter selvmord og selvmordsforsøk (Helsedirektoratet, 1993).

Fra et kvinnehelseperspektiv synes særlig det betydelige omfanget av selvmordsforsøk og selvpåførte skader blant unge kvinner å representere et viktig helseproblem og en utfordring både med tanke på å bedre helse og livskvalitet og å forebygge tidlig død i denne befolkningsgruppen.

\section{NOTER}

(1) Tallene er basert på sammenstillinger av opplysninger fra Statistisk Sentralbyrås oppgaver over dødsårsaker for årene 1975 t.o.m. 1991.

(2) En studie fra Finland viste en noe høyere forekomst av selvmordsforsøk blant menn enn blant kvinner (Ostamo \& Lönnqvist, 1994).

(3) Begrepet "parasuicid" er derfor introdusert som et mer presist begrep enn selvmordsforsøk (Kreitman, 1977; ICD 10. revisjon), men "selvmordsforsøk" er et innarbeidet og vanlig brukt begrep.

\section{REFERANSER}

Bjerke T. Selvmordsatferd blant studenter og andre grupper unge voksne. Tidsskr Nor Psykologforen 1990; 27: 438-446.

Bjerke T. Selvmord og selvmordsforsøk blant unge. Trondheim: Tapir, 1991. 
Burmo B, Sveum BD, Dieserud G, Borg SE. Selvmordsforsøk i Bærum 1984-1988. Rapport om det oppfølgende arbeid etter selvmordsforsøk i Bærum kommune. Bærum: Helseetaten i Bærum, 1990.

Hammerlin Y, Schjelderup G. Når livet blir en byrde. Selvmordsforståelse og problemer ved forebygging. Oslo: ad Notam, 1994.

Haukø W. Selvmordsforsøk hos ungdom under 18 år behandlet av Bærum sykehus fra 1989 til 1994. I: Marthinsen E, Ekberg K (red.). Artikkelsamling fra nordiske symposium om forskning i sosialt arbeid. Et møte mellom forskning og praksis. Trondheim: Norsk senter for barneforskning.

Hawton K, O'Grady J, Osborn M, Cole D. Adolescents who take overdoses: their characteristics, problems and contacts with helping agencies. Br J Psychiatry 1982; 140: 118-123.

Helsedirektoratet. Nasjonalt program for forebygging av selvmord i Norge. Helsedirektoratets utredningsserie 193. Oslo: 1993.

Hjelmeland H, Bjerke T. The epidemiology of parasuicide in Sør-Trøndelag 1989-1991. I: Kerkhof AJFM, Schmidtke A, Bille-Brahe U, deLeo D, Lönnqvist J (red.). Attempted suicide in Europe. Findings from the multicentre study on parasuicide by the WHO regional office for Europe. Leiden: DSWO Press, 1994.

Hjelmeland H. Verbally expressed intentions of parasuicide II. Predicition of fatal and nonfatal repetition. Crisis 1996; 17: 1014.

Hjelmeland H. Parasuicid (selvmordsforsøk) - epidemiologiske aspekter. I: Mehlum L (red.). Tilbake til livet. Selvmordsforebygging i teori og praksis. Oslo: Høyskoleforlaget, 1999.

Hytten K, Mæhlum L, Gjertsen F. Rom for unge liv. Oslo: Universitetet i Oslo, 1995.

Jack R. Women and attempted suicide. Hillsdale, USA: Lawrence Erlbaum Ass., 1992.

Jessen G, Andersen K, Bille-Brahe U. Selvmordstanker og selvmordsforsøg blant 15-24 årige i det danske uddannelsessystem. Ugeskr Lager 1996; 158: 5026-5029.

Kerkhof AJFM, Schmidtke A, Bille-Brahe U, deLeo D, Lönnqvist J. Attempted suicide in Europe. Findings from the multicentre study on parasuicide by the WHO regional office for Europe. Leiden: DSWO Press, 1994.

Maris RW, Berman AL, Maltsberger JT, Yufit RI (red.). Assessment and prediction of suicide. New York: Guilford Press, 1992.

Ostamo A, Lönnqvist J. The epidemiology of attempted suicide in Helsinki, Finland. I:

Retterstøl N. Selvmord. Oslo: Universitetsforlaget, 1995.

Rossow I, Wichstrøm L. Parasuicide and use of intoxicants in Norwegian adolescents. Suicide Life Threat Behavior 1994; 24: 174-183.

Rossow I, Wichstrøm L. Når nøden er størst - er hjelpen nærmest? Hjelp og behandling etter selvmordsforsøk blant ungdom. Tidsskr Nor Logeforen 1997; 117: 1740-1743.

Rygnestad T. Suicidal atferd i Norge. Asker: Organon, 1991.

Statistisk Sentralbyrå. Dødsårsaker 1995. Norges offisielle statistikk. Oslo: Statistisk sentralbyrå, 1998. 